\title{
Effect of sulfonamide antibiotics on microbial diversity and activity in a Californian Mollic Haploxeralf
}

\author{
Iris R. Gutiérrez - Naoko Watanabe - Thomas Harter • \\ Bruno Glaser • Michael Radke
}

\begin{abstract}
Purpose Up to $90 \%$ of antibiotics that are fed to livestock are excreted unaltered or as metabolites and thus are present in manure. By application of manure as fertilizer, veterinary antibiotics can reach soil and groundwater. The aim of this study is to determine the effect of three commonly used (and simultaneously applied) sulfonamide antibiotics on both function and structural diversity of soil microorganisms. To this end, the activity of the enzymes urease and dehydrogenase was determined, and the composition of phospholipid fatty acids (PLFA) was analyzed.

Materials and methods Soil and manure were sampled at a dairy farm located in the Northern San Joaquin Valley, California, USA. Soil (700 g) was amended with either mineral water only (W-treatments), liquid manure (M-treatments), or with glucose solution (G-treatments). Each of these soil treatments was mixed with a cocktail of three sulfonamides: sulfadimethoxine (SDT), sulfamethoxazole (SMX), and sulfamethazine (SMZ) at five total concentration levels ranging from 0 (control) to $900 \mu \mathrm{g} \mathrm{g}_{\mathrm{dm}}{ }^{-1}$. After $24,48,96,168,264$,
\end{abstract}

\author{
I. R. Gutiérrez $\cdot$ M. Radke $(\triangle)$ \\ Department of Hydrology, BayCEER, University of Bayreuth, \\ 95440 Bayreuth, Germany \\ e-mail: michael.radke@uni-bayreuth.de \\ N. Watanabe $\cdot$ T. Harter \\ Department of Land, Air and Water Resources, \\ University of Califormia, \\ Davis, CA 95616-8628, USA \\ B. Glaser \\ Department of Soil Physics, BayCEER, University of Bayreuth, \\ 95440 Bayreuth, Germany
}

384, and $504 \mathrm{~h}$, UA and DHA were determined; PLFA composition in selected samples was analyzed at $t=168 \mathrm{~h}$ and $504 \mathrm{~h}$ of incubation.

Results and discussion In the G-treatments, urease activity decreased with higher sulfonamide concentrations; no effect was observed when no glucose was added (W-treatments). While a dose-response relationship was observed for urease activity after $168 \mathrm{~h}$, a similar inhibition was measured after $380 \mathrm{~h}$ at all sulfonamide concentrations. Sulfonamides also reduced dehydrogenase activity in the G-treatments, but results are less conclusive than for urease. With increasing sulfonamide concentration, microbial and bacterial biomass decreased in the G-treatments compared to the control at 168 h. Sulfonamides caused a relative community shift towards gram-negative bacteria and towards an increased proportion of fungal biomass. Strong inhibition of urease by manure (M-treatments) was observed even without the addition of sulfonamides.

Conclusions Sulfonamides clearly affected both the function and structural diversity of the soil microbial community over at least 16 days. The soil microbial community was affected by sulfonamides even at a relatively low concentration, although this soil receives regular input of manure that contains several antibiotics. Further research is needed addressing both long-term effects and lower sulfonamide concentrations under dynamic boundary conditions.

Keywords Antibiotics - Dehydrogenase - Enzyme activity . Phospholipid fatty acids · Soil microorganisms · Urease

\section{Introduction}

The use of antibiotics in livestock farming is a worldwide practice. Antibiotics are administered to livestock either to prevent or to cure diseases. They are also used as growth 
promoters. According to Sarmah et al. (2006), sulfonamides make up $2.3 \%$ of all antibiotics used in the United States. Sulfonamides - a class of synthetic antimicrobial drugsinterrupt the bacterial synthesis of folic acid which is essential for the synthesis of bacterial DNA (Madigan et al. 2009). Therefore, they have a bacteriostatic effect (i.e., they limit bacterial growth) rather than bacteriocidal effects. Up to $90 \%$ of antibiotics that are fed to livestock are excreted unaltered or as metabolites (Halling-Sørensen et al. 1998), and they are detectable in manure, soil, and groundwater (Hamscher et al. 2005). A major pathway of antibiotics in animal waste is the application of manure as fertilizer on forage crops. To date, little is known about their effects on microbial soil biota in these agronomic systems.

The influence of antibiotics on soil microbial biomass can be studied by monitoring changes in enzyme activities, microbial biomass, basal or substrate-induced respiration (Kotzerke et al. 2008; Thiele-Bruhn and Beck 2005), or microbial diversity (Hammesfahr et al. 2008; Kong et al. 2006), although few examples are currently available in the literature. In recent studies (Hammesfahr et al. 2008; Zielezny et al. 2006), the influence of both manure and sulfonamides on microbial community patterns in different soils was evaluated by measuring phospholipid fatty acids (PLFA) profiles and polymerase chain reaction (PCR)denaturing gradient gel electrophoresis (DGGE) of $16 \mathrm{~S}$ rDNA. Changes in microbial community patterns due to antibiotics were observed in these studies. However, effects of sulfonamides were only observed after the input of a carbon source like glucose, straw, or manure which initiated bacterial growth (Hammesfahr et al. 2008; Schmitt et al. 2005; Thiele-Bruhn and Beck 2005; Zielezny et al. 2006).

The aim of this study is to determine the effect of sulfonamide antibiotics on structural diversity and function of the soil microbial community. To this end, laboratory incubation experiments under controlled conditions were carried out using soil and manure sampled from a California dairy farm. As indicators for functional changes, we measured the activities of two enzymes, urease and dehydrogenase, as function of sulfonamide concentration. While dehydrogenase is a measure for general microbial activity, urease is more specifically related to the nitrogen cycle and was selected because of its importance for the release of $\mathrm{N}$ from manure. PLFA analyses were used to determine structural changes of the soil microbial community.

\section{Materials and methods}

\subsection{Soil and manure}

Soil and manure were sampled at a dairy farm located in the Northern San Joaquin Valley, California, USA. For details on dairy farm operation refer to Watanabe et al. (2008) and Harter et al. (2002). The soil studied was collected from an agricultural field that receives manure from one of the dairies for irrigation and fertilization. The soil is classified as Mollic Haploxeralf (Oakdale sandy loam); soil texture was loamy sand $(85.5 \%$ sand, $8.5 \%$ silt, $6.0 \%$ clay). Approximately 2 weeks prior to sampling, the field was tilled by ripping and disking before it was irrigated with liquid manure from the dairy farm lagoon for $12 \mathrm{~h}$. The field is operated each year by crop rotation with transgenic corn (so-called roundup ready corn; Zea mays), followed by sudangrass (Sorghum bicolor), and triticale (Triticosecale). Soil was sampled from a depth of $10-40 \mathrm{~cm}$ below the surface after vegetation residues were removed. The soil was sieved to $<2 \mathrm{~mm}$ and stored in the dark at $4^{\circ} \mathrm{C}$ until use. The soil was characterized by a $\mathrm{pH}$ of 6.6 , an organic carbon content of $0.86 \%$, a $\mathrm{C}: \mathrm{N}$ ratio of 8.2 and a cation exchange capacity of $8.1 \mathrm{cmol} \mathrm{kg}^{-1}$. Additional data on major elements and nutrients is available as Supplementary Material.

Liquid manure was sampled from the storage lagoon at the dairy farm. Liquid waste is collected from flushlanes in freestalls housing approximately 3,000 animals (1,500 lactating cows, and 1,500 support stock) after separating solids in settling basins. Due to the operation of the collection system, the manure contains a relatively large proportion of water and thus is - compared to 'typical' European manure-more dilute. Samples were taken from the lagoon and stored at $-18^{\circ} \mathrm{C}$ until use. The concentration of dissolved organic carbon (DOC) in the manure was $24 \mathrm{mg} \mathrm{L}^{-1}$, the $\mathrm{NH}_{4}-\mathrm{N}$ concentration was $272 \mathrm{mg} \mathrm{L}^{-1}$. The $\mathrm{pH}$ of the manure was 7.8 , and the concentration of total dissolved solids (TDS) was approx. $4,060 \mathrm{mg} \mathrm{L}^{-1}$. A typical dose of 6 to $17 \mathrm{mg}$ $\operatorname{cow}^{-1}$ day $^{-1}$ of individual sulfonamides was administered in the studied dairy farms, corresponding to a total applied mass of each compound between 10 to $25 \mathrm{~g} \mathrm{farm}^{-1} \mathrm{day}^{-1}$ (Watanabe et al., unpublished). The specific batch of manure used for this study was not analyzed for pharmaceuticals, but generally several pharmaceuticals are present in the manure: sulfonamides $(0.030$ $\left.14 \mu \mathrm{g} \mathrm{L}^{-1}\right)$, trimethoprim $\left(0.024 \mu \mathrm{g} \mathrm{L}^{-1}\right)$, tetracyclines and their degradation products $\left(0.020-1.53 \mu \mathrm{g} \mathrm{L}^{-1}\right)$, and lincomycin (0.012-0.054 $\mu \mathrm{g} \mathrm{L}^{-1}$; Watanabe et al., unpublished). Additional data on manure composition is available as Supplementary Material.

\subsection{Incubation experiments}

The effect of sulfonamides was studied using a composite mixture of the three compounds sulfadimethoxine (SDT), sulfamethoxazole (SMX), and sulfamethazine (SMZ) as these typically do not occur separately in dairy farm manure. Soil treatments and sulfonamide levels in the soil were the two experimental variables (Table 1). For each 
Table 1 Summary of experimental conditions. The following nomenclature was used for all experiments: Treatment Sulfonamide Concentration, for example W_90

\begin{tabular}{llll}
\hline Sulfonamide concentration $\left(\mu \mathrm{g}_{\mathrm{dn}}{ }^{-1}\right)$ & \multicolumn{2}{l}{ Type of solution } & \\
\cline { 2 - 4 } & Water $(\mathrm{W})$ & Glucose $(\mathrm{G})$ & Manure (M) \\
\hline 0 & $\mathrm{X}$ & $\mathrm{X}$ & $\mathrm{X}$ \\
0.9 & & $\mathrm{X}$ & \\
9 & & $\mathrm{X}$ & \\
90 & $\mathrm{X}$ & $\mathrm{X}$ & $\mathrm{X}$ \\
900 & $\mathrm{X}$ & $\mathrm{X}$ & $\mathrm{X}$ \\
\hline
\end{tabular}

incubation, $700 \mathrm{~g}$ soil were transferred to a plastic container $(V=1,500 \mathrm{~mL})$ and acclimated to the incubation temperature of $20^{\circ} \mathrm{C}$ for 7 days. Three soil treatments were prepared: a water-only soil treatment (W-treatment), a manureamended soil treatment (M-treatment), and a glucoseamended soil treatment (G-treatment). For the M-treatment only, the soil was amended with $175 \mathrm{~mL}$ of manure prior to the acclimation period. After the acclimation period, the soil was transferred in portions of approx. $150 \mathrm{~g}$ to a new container, and the water content was adjusted to $50 \%$ of the water holding capacity by sprinkling mineral water (W- and M-treatments), or glucose solution (G-treatment; corresponding to a final glucose (99\%; Sigma-Aldrich, Seelze, Germany) concentration of $1,000 \mu \mathrm{g} \mathrm{gdm}^{-1}$. Due to their limited water solubility, the sulfonamides could not be added with the water/glucose solution or with the manure. Instead, $40 \mathrm{~g}$ of the acclimated soil were mixed with the desired amount of antibiotics, and added in small portions to $660 \mathrm{~g}$ of soil which was thoroughly mixed. For the W- and Mtreatment, two levels of antibiotic amendments were tested, for the G-treatment we tested four levels of antibiotic amendments. Final concentrations of antibiotics were 0 (control), 0.9 (glucose only), 9 (glucose only), 90, and $900 \mu \mathrm{g} \mathrm{g}_{\mathrm{dm}}^{-1}$ (see Table 1). For all experiments, sulfonamides were applied as a mixture containing equal mass of SDT, SMX, and SMZ (purity $\geq 99 \%$; Sigma-Aldrich), where the above concentrations reflect the sum of the three sulfonamides. The containers were closed with perforated lids to facilitate gas exchange and incubated at $20^{\circ} \mathrm{C}$ in the dark. Every second day, soil moisture was adjusted to the initial water content. For the determination of urease and dehydrogenase activities (UA, and DHA, respectively), three replicate samples $(5 \mathrm{~g})$ for each enzyme were sampled after $24,48,96,168,264,384$, and $504 \mathrm{~h}$ and analyzed immediately. Samples for PLFA analyses $(10 \mathrm{~g})$ were taken after 168 and $504 \mathrm{~h}$ and stored frozen until analysis.

\subsection{Determination of enzyme activities}

For the determination of UA, a method described by Kandeler and Gerber (1988) was used. Briefly, $5 \mathrm{~g}$ of soil was transferred from the incubation containers to $100 \mathrm{~mL}$ PE bottles and $2.5 \mathrm{~mL}$ of $79.9 \mathrm{mM}$ aqueous urea solution
( $\geq 99.5 \%$, Roth, Karlsruhe, Germany; control series: distilled water) was added. After incubation for $2 \mathrm{~h}$ at $37^{\circ} \mathrm{C}$, $2.5 \mathrm{~mL}$ of distilled water (controls: urea solution as above) and $50 \mathrm{~mL}$ of a $\mathrm{KCl}-\mathrm{HCl}$ solution $(\mathrm{c}(\mathrm{KCl})=1 \mathrm{M} ; \mathrm{c}(\mathrm{HCl})=$ $0.01 \mathrm{M})$ were added to extract the degradation product $\mathrm{NH}_{4}{ }^{+}$. The samples were shaken for $30 \mathrm{~min}$ on the horizontal rotary shaker, then the supernatant was filtered, and the ammonium concentration was determined spectrophotometrically $\left(\mathrm{NH}_{4}{ }^{+}\right.$-test, Spectroquant, Merck, Darmstadt, Germany) at a wavelength of $690 \mathrm{~nm}$. The results were corrected for the $\mathrm{NH}_{4}{ }^{+}$-concentrations determined in blank samples. UA is reported as production rate of $\mathrm{NH}_{4}{ }^{+}-\mathrm{N}$ per $\mathrm{g}$ dry soil mass and incubation time (micrograms $\mathrm{N}$ per gram $\left._{\mathrm{dm}} 2 \mathrm{~h}^{-1}\right)$. For the determination of DHA, the transformation of 2,3,5-triphenyltetrazolium chloride (TTC; p.a. quality, Fluka, Seelze, Germany) to 1,2,5-triphenyl formazan (TPF; p.a. quality, Fluka) was employed (Thalmann 1968). Five milliliters of an aqueous TTC solution $(0.3 \%)$ and $5 \mathrm{~mL}$ of a buffer solution ( $0.1 \mathrm{M}$ tris(hydroxymethyl) aminomethane ( $\geq 99.8 \%$, Merck) adjusted with $\mathrm{HCl}(32 \%)$ to $\mathrm{pH} 7.6$ ) were added to $5 \mathrm{~g}$ of field-moist soil in $30 \mathrm{~mL}$ glass flasks, and samples were incubated for $16 \mathrm{~h}$ at $30^{\circ} \mathrm{C}$. To blank samples, no TTC solution was added. The produced TPF was extracted with $25 \mathrm{~mL}$ of acetone by shaking for $2 \mathrm{~h}$ on a horizontal rotary shaker. Subsequently, the solution was filtered and the TPF concentration was determined spectrophotometrically (wavelength $546 \mathrm{~nm}$ ). Similar to UA, DHA is reported as micrograms TPF per $\operatorname{gram}_{\mathrm{dm}} 16 \mathrm{~h}^{-1}$.

\subsection{Analysis of phospholipid fatty acids}

Phospholipids extraction from soil was carried out according to the method described by Schmitt et al. (2008) which is in principle based on that by Frostegard et al. (1991). A composite stock solution was produced from neat PLFA standards ( $\geq 98 \%$ ) obtained from various suppliers. Nomenclature used for individual PLFA, purity of neat compounds, and the list of suppliers is available in the Supplementary Material. The internal standard PLFA 19:0 and FAME 13:0 ( $\geq 99 \%)$ were purchased from Biotrend and Sigma-Aldrich, respectively. After thawing to room temperature, $5 \mathrm{~g}$ soil were mixed with $18 \mathrm{~mL}$ of extraction solution (1:2:0.8 chloroform:methanol:citrate buffer, citrate 
buffer: $6.3 \mathrm{~g}$ citric acid monohydrate in $200 \mathrm{~mL}$ de-ionized water, adjusted to $\mathrm{pH} 4.0$ with $\mathrm{KOH}$ pellets). The mixture was shaken for $2 \mathrm{~h}$ at $225 \mathrm{rpm}$ on a horizontal rotary shaker and subsequently centrifuged (4,000 rpm for $20 \mathrm{~min})$. The supernatant was transferred to a separation funnel and the residue was extracted a second time $(5 \mathrm{~mL}$ extraction solution, $1 \mathrm{~h}$ shaking) and centrifuged. The supernatant from the second extraction step was also transferred into the separation funnel. Then, $15 \mu \mathrm{g}$ of PLFA 19:0 (internal standard), $6.2 \mathrm{~mL}$ of chloroform and $6.2 \mathrm{~mL}$ of citrate buffer were added. The separation funnel was shaken vigorously by hand and subsequently by a horizontal rotary shaker $(225 \mathrm{rpm})$ for $10 \mathrm{~min}$. After phase separation (overnight), the chloroform phase containing the lipids was transferred into $25 \mathrm{~mL}$ conical flasks and dried using a rotary evaporator. The residue was re-dissolved in chloroform. The phospholipids were fractionated on glass columns filled with silica gel by sequential elution with $5 \mathrm{~mL}$ chloroform, $20 \mathrm{~mL}$ acetone, and $2 \times 10 \mathrm{~mL}$ methanol. The combined methanolic fractions containing the phospholipids were dried with a rotary evaporator, and after re-dissolution with methanol the extract was transferred into a 4-mL glass reaction vial and again dried under a stream of nitrogen. Afterwards, the samples were subjected to a strong acid methylation with boron trifluoride (Fluka) in methanolic solution to derivatize free PLFA to fatty acid methyl esters (FAME). After derivatization, samples were again evaporated to dryness under a stream of nitrogen and stored frozen $\left(-18^{\circ} \mathrm{C}\right)$ until further processing. For quantification, standards containing the target PLFA were also derivatized using the same procedure. Prior to analysis, $25 \mu \mathrm{L}$ of 13:0 FAME $\left(c=1 \mathrm{mg} \mathrm{mL}^{-1}\right)$ in toluene as instrumental standard and $175 \mu \mathrm{L}$ toluene were added, and the solution was transferred to a vial. FAME were quantified using a gas chromatograph with flame ionization detector (HP 6890, Agilent, Waldbronn, Germany). Separation was carried out on a fused silica capillary column (SPB 5,60 m× $0.25 \mathrm{~mm} \times 0.25 \mu \mathrm{m}$, Supelco, Seelze, Germany); Helium was used as carrier gas with a constant flow rate of $2.4 \mathrm{~mL} \mathrm{~min}^{-1}$. Quantification was based on the internal standards method.

PLFA were assigned to taxonomic groups based on recent literature (Hackl et al. 2005; Zelles 1999). Terminalbranched saturated PLFA a15:0, i15:0, i16:0, i17:0, and a17:0 were used as markers for gram-positive bacteria $\left(\right.$ PLFA $\left._{\mathrm{g}+}\right)$; gram-negative bacteria (PLFA $\mathrm{g}_{-}$) were quantified by monounsaturated PLFA $(16: 1 \omega 7 \mathrm{c}, 18: 1 \omega 7 \mathrm{c}$, 18:1 $\omega 9 \mathrm{c}$ ) and cyclopropyl saturated PLFA (cy 17:0, cy 19:0). The sum of signature PLFA for gram-positive and -negative bacteria is referred to as bacterial PLFA $\left(\right.$ PLFA $\left._{\text {bact }}\right)$. The quantity of the PLFA 18:2 $\omega 6,9$ was used as an indicator of fungal biomass since it is suggested to be mainly of fungal origin in soil (Hackl et al. 2005). In addition, the following compounds were determined and incorporated in the parameter PLFA tot $_{\text {as }}$ a measure for total microbial biomass: 10Me16:0, 10Me17:0, 10Me18:0, $20: 4 \omega 6,16: 1 \omega 5 \mathrm{c}, 14: 0,15: 0,16: 0,17: 0$, and 18:0.

\subsection{Calculations}

Three replicate samples were collected from each treatment for enzyme analysis at each time step. The results for the different levels of antibiotics were analyzed for significant differences to the control and among each other using Fisher's Least Significant Difference (LSD) test at a significance level of 0.05 after verifying significance by Analysis of Variance (ANOVA; Snedecor and Cochran 1989).

\section{Results}

\subsection{Urease activity}

The baseline UA in the control W-treatment, W_0, was on average $14 \pm 1 \mu \mathrm{g} \mathrm{N} \mathrm{g} \mathrm{dm}^{-1} 2 \mathrm{~h}^{-1}$. The addition of sulfonamides caused no significant difference of UA in treatments W_90 and W_900 with average activities of $11 \pm 2$ and $13 \pm$ $1 \mu \mathrm{g} \mathrm{N} \mathrm{gdm}{ }^{-1} 2 \mathrm{~h}^{-1}$, respectively. Therefore, no effect of sulfonamides on UA was observed. For all W-treatments, UA was relatively constant over time as is exemplified for treatment W_90 in Fig. 1a.

The G-treatment resulted in significantly higher UA than the W-treatment: in the control, G_0, UA was $70 \pm 7 \mu \mathrm{g} \mathrm{N}$ $\mathrm{g}_{\mathrm{dm}}^{-1} 2 \mathrm{~h}^{-1}(t=163 \mathrm{~h})$ and $62 \pm 9 \mu \mathrm{g} \mathrm{N} \mathrm{g} \mathrm{dm}^{-1} 2 \mathrm{~h}^{-1}(t=$ $380 \mathrm{~h}$ ), respectively. In contrast to the $\mathrm{W}$-treatment, UA was significantly inhibited at all sulfonamide levels in the Gtreatment relative to the control G-treatment (Fig. 2a). At $163 \mathrm{~h}$, the inhibition of UA increased with sulfonamide levels ( $G_{-} 0.9<G_{-} 9 \approx G 90<G_{-} 900$ ), whereas the inhibition after $380 \overline{\mathrm{h}}$ was not significantly different for all levels. This occurred as the inhibition of UA approximately doubled at the lowest sulfonamide level (G_0.9) from 163 to $380 \mathrm{~h}$, whereas it decreased for all other treatments over that time period.

In the control M-treatment (M 0; see Fig. 1a), UA was initially completely inhibited, but recovered over incubation time to the same level as W_0. A similar behavior was observed for treatment M_90. However, the temporal dynamics of UA in treatment M_900 were completely different: initially, UA was identical to the $W_{-} 0$ treatment, then decreased exponentially $\left(R^{2}=0.96\right)$ with a final UA lower than that of the M_0 or W_0 treatments (see Fig. 1a).

\subsection{Dehydrogenase activity}

DHA of the W_0 treatment averaged $30 \pm 11 \mu \mathrm{g}$ TPF $\mathrm{g}_{\mathrm{dm}}{ }^{-1}$ $16 \mathrm{~h}^{-1}$. Similar to UA, the addition of sulfonamides caused no significant changes of DHA in treatments W_90 and 
a

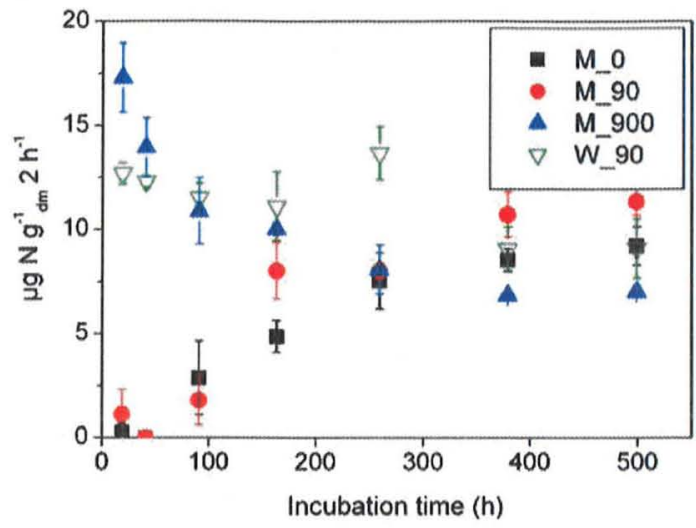

b

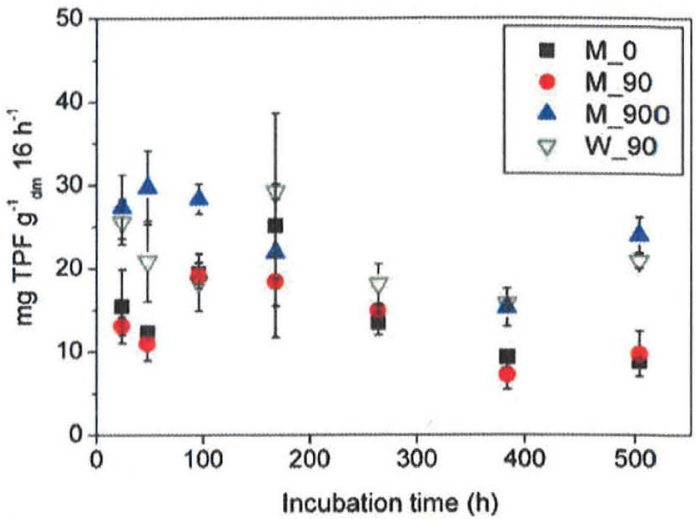

Fig. 1 Temporal trends of enzyme activities in the manure treatments and treatment W_90. a Urease activity; b dehydrogenase activity. Error bars represent standard deviation of replicates $(n=3)$

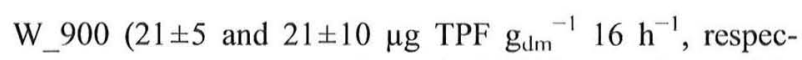
tively). No clear temporal trend of DHA was observed in the W-treatments, as is shown in Fig. $1 \mathrm{~b}$ for the W 90 treatment.

When the soil was amended with glucose, a significant $(p<0.05)$ inhibition of DHA was observed at all sulfon-

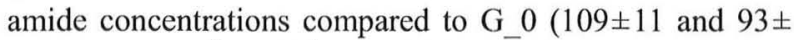
$8 \mu \mathrm{g} \mathrm{TPF} \mathrm{g}_{\mathrm{dm}}^{-1} 16 \mathrm{~h}^{-1}$ after 168 and $384 \mathrm{~h}$, respectively). However, the pattern was markedly different from that for UA: the inhibiting effect was highest at the lowest sulfonamide level and then decreased with higher sulfonamide levels (see Fig. 2b). The results for G 90 at $168 \mathrm{~h}$ and for G 900 at $t=384 \mathrm{~h}$ are exceptional since UA is not significantly different from the G_0 control. Analytical problems are unlikely to be the reason for these exceptions since results for replicates were reproducible.

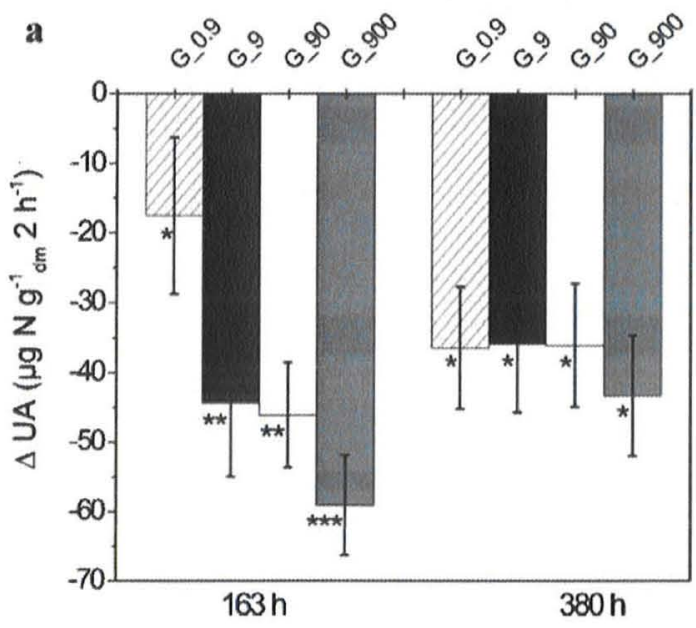

Fig. 2 Change of enzyme activity relative to the glucose treatment G_0 for two sampling steps. a Urease activity at $\mathrm{t}=163 \mathrm{~h}$ and $t=380 \mathrm{~h}$; b dehydrogenase activity at $t=168 \mathrm{~h}$ and $t=384 \mathrm{~h}$. Results that were significantly different $(p<0.05)$ from the activity in the control treatment
DHA in the M_0 treatment (10 to $25 \mu \mathrm{g}$ TPF $\mathrm{gdm}^{-1}$ $16 \mathrm{~h}^{-1}$ ) was in the same range as in the W_0 treatment. The results for treatment M 90 were similar to M 0 , whereas DHA in M_900 was higher than in the other treatments at the beginning and at the end of the incubation period but not at intermediate times. DHA peaked markedly later in the M_0 and M_90 treatments than in the M_900 treatment. Overall, no simple temporal trend of DHA was observed in the M-treatments (see Fig. 1b).

\subsection{Microbial biomass and community structure (PLFA)}

At $t=168 \mathrm{~h}$, microbial biomass determined by PLFA tot $_{\text {was }}$ slightly lower in the G-treatment control (G_0) than in the W-treatment control (W_0), whereas the M-treatment (M_0) was highest and had approximately $20 \%$ larger

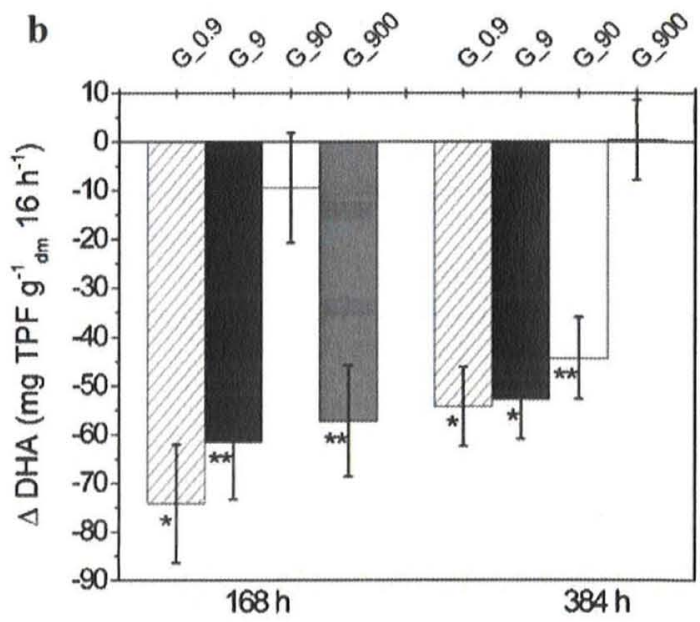

G 0 are indicated by one or more asterisks. Treatments that did not significantly differ from each other are labeled with the same number of asterisks. Error bars represent standard deviation of replicate analyses $(n=3$; for DHA/G_90/168 h and DHA/G_900/384 h: $n=2)$ 
microbial biomass compared to W 0 . Higher sulfonamide levels substantially decreased PLFA ${ }_{\text {tot }}$ at $168 \mathrm{~h}$ (Table 2). Microbial biomass in treatment $\mathrm{G} 90$ almost doubled between $t=168 \mathrm{~h}$ and $t=504 \mathrm{~h}$, whereas it remained constant both in $\mathrm{G}_{900}$ and $\mathrm{M} \mathrm{0}$. Bacterial biomass $\left(\mathrm{PLFA}_{\text {bact }}\right)$ was of similar magnitude in $\mathrm{G}_{-} 0$ and $\mathrm{W}_{-} 0$ after $t=168 \mathrm{~h}$ (see Table 2). In the G-treatments, PLFA $A_{\text {bact }}$ was lower when sulfonamides were added; PLFA bact $_{\text {decreased }}$ with increasing sulfonamide level. The effect of sulfonamides on gram-positive bacteria was higher than on gramnegative bacteria (see Table). In the absence of sulfonamides, PLFA concentration of gram-positive bacteria was similar for treatments $\mathrm{G}_{-} \mathrm{O}$ and $\mathrm{M}_{-} 0$, whereas microbial biomass of gram-negative bacteria in treatment $\mathrm{M}_{-} 0$ was higher. For treatment G_90, concentrations of both gram-positive and negative bacteria increased between $t=168 \mathrm{~h}$ and $t=504 \mathrm{~h}$. In contrast, for treatment G_900 the concentration of grampositive bacteria increased from 99 to $114 \mathrm{nmol} \mathrm{g}_{\mathrm{dm}}^{-1}$ while it remained constant for gram-negative bacteria. In the M_0 treatment, bacterial biomass did not change from $t=168 \mathrm{~h}$ to $t=504 \mathrm{~h}$.

Fungal biomass was lowest in treatment $\mathrm{W}_{-} 0$, and no clear effect of sulfonamides on fungal biomass was observed. This holds also true for the temporal trends where we observed both increasing $\left(G_{-} 90\right)$ and decreasing (G_900) fungal PLFA concentrations from $t=168 \mathrm{~h}$ to $t=504 \mathrm{~h}$.

\section{Discussion}

The dose-response relationship in the glucose treatments between sulfonamides and both UA ( $t=163 \mathrm{~h}$; see Fig. 2) and microbial and bacterial biomass ( $t=168 \mathrm{~h}$; see Table 2$)$ can be attributed to the antibiotic effect of sulfonamides. The effect on UA was even observed at concentrations as low as $0.9 \mu \mathrm{g} \mathrm{g}_{\mathrm{um}}{ }^{-1}$. The response of DHA to increasing sulfonamide concentrations was less clear. Generally, DHA was substantially reduced when sulfonamides were present, but it appears that DHA inhibition was highest at the lowest sulfonamide level and decreased with increasing concentration of sulfonamides (see Fig. 1b). The stimulation of bacterial growth was necessary to observe these effects, at least on the timescale analyzed in this study. This is similar to observations by Thiele-Bruhn and Beck (2005) and Zielezny et al. (2006), and it complies with the bacteriostatic effect of sulfonamides which should be most pronounced when growth is promoted. The lower PLFA concentrations in treatments G_90 and G_900 compared to G_ 0 are consistent with the findings of Thiele-Bruhn and Beck (2005). Under similar conditions (glucose addition, incubation time of 14 days), they reported the reduction of microbial biomass at $1,000 \mu \mathrm{g} \mathrm{g}_{\mathrm{dm}}{ }^{-1}$ of sulfapyridine by approx. $55 \%$ compared to the control, whereas a sulfapyridine concentration of $100 \mu \mathrm{g} \mathrm{g}_{\mathrm{dm}}{ }^{-1}$ decreased microbial biomass by only approx. $10 \%$. Moreover, the similar effects

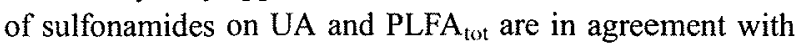
results by Klose and Tabatabai (1999) who reported a correlation of microbial biomass with UA. When comparing the results of our experiments to previous studies, it should be taken into account that the soil used here was regularly exposed to sulfonamide inputs via manure while most previous studies used soils with no history of antibiotics' application. Nevertheless, the general effects observed on the microbial community in this pre-exposed soil were similar to those observed in other soil/manure systems.

In contrast to $t=163 \mathrm{~h}$, the inhibition of UA at $t=380 \mathrm{~h}$ was independent of sulfonamide dose at all tested levels (see Fig. 2a). Although we did not analyze the bioavailable sulfonamide concentration in our incubations, we do not expect a similar bioavailability of sulfonamides (i.e., that is independent from the initial concentration) to be the reason for this result. Bioavailability is reduced by an increased sorption of sulfonamides with time (Kahle and Stamm 2007 ), by primary degradation (=deactivation), or by the formation of non-extractable residues (Heise et al. 2006). However, as shown by Kotzerke et al. (2008) for sulfadiazine, we still would expect a higher bioavailability at higher initial concentration and thus a dose-dependent inhibition at $t=$ $380 \mathrm{~h}$. Thus, the similar UA at $t=380 \mathrm{~h}$ can most likely be attributed to one of the following reasons:

(1) Factors other than sulfonamides (e.g., organic carbon/glucose, nutrients) could be exhausted during the experiment and thus limiting UA. The reduced UA in the G_0 treatment $\left(-8 \mu \mathrm{g} \mathrm{N} \mathrm{g} \mathrm{dm}^{-1} 2 \mathrm{~h}^{-1}\right)$ between $163 \mathrm{~h}$ and $380 \mathrm{~h}$ points to this direction. However, no information on such potentially limiting parameters for the different treatments is available to back-up this explanation.

(2) Microorganisms tolerant to sulfonamides could have provided the observed UA: bacteria resistant to several antibiotics (sulfonamides were not tested) have been previously identified both in dairy farm manure and garden soil fertilized with farm manure (Esiobu et al. 2002), and an increase of tolerance of microorganisms against another sulfonamide over time has also previously been shown (Schmitt et al. 2004). Thus, if microorganisms susceptible to sulfonamides were effectively inhibited, the 'baseline' UA measured at $t=380 \mathrm{~h}$ may have been provided by bacteria tolerant to or resistant against sulfonamides.

The addition of sulfonamides caused a relative bacterial community shift towards gram-negative bacteria. Moreover, the addition of sulfonamides overall lead to an increased proportion of fungal biomass compared to bacterial biomass (see Table 2). This shift of microbial community structure towards fungi is in line with findings 
Table 2 PLFA concentrations (nmol gdm ${ }^{-1}$; indices: $\mathrm{g}^{+}$ gram-positive, g- gram-negative, bact sum of gram-positive and -negative bacteria, fungi fungal markers, tot sum of all analyzed PLFA) of selected microbial groups in differen treatments at $t=168$ and $t=504 \mathrm{~h}$

$n / a$ not analyzed

\begin{tabular}{|c|c|c|c|c|c|c|c|c|c|c|}
\hline & \multicolumn{2}{|c|}{$\mathrm{PLFA}_{\underline{\underline{y}}}$} & \multicolumn{2}{|c|}{ PLFA $_{g_{--}}$} & \multicolumn{2}{|c|}{ PLFA $_{\text {bact }}$} & \multicolumn{2}{|c|}{ PLFA $_{\text {fungi }}$} & \multicolumn{2}{|c|}{ PLFA $_{\text {tot }}$} \\
\hline & $168 \mathrm{~h}$ & $504 \mathrm{~h}$ & $168 \mathrm{~h}$ & $504 \mathrm{~h}$ & $168 \mathrm{~h}$ & $504 \mathrm{~h}$ & $168 \mathrm{~h}$ & $504 \mathrm{~h}$ & $168 \mathrm{~h}$ & $504 \mathrm{~h}$ \\
\hline $\mathrm{G}_{-} 0$ & 246 & $n / a$ & 281 & $\mathrm{n} / \mathrm{a}$ & 527 & $\mathrm{n} / \mathrm{a}$ & 36 & $\mathrm{n} / \mathrm{a}$ & 856 & $\mathrm{n} / \mathrm{a}$ \\
\hline G 90 & 152 & 269 & 265 & 420 & 417 & 689 & 28 & 42 & 773 & 1,259 \\
\hline G_900 & 99 & 114 & 177 & 173 & 276 & 287 & 34 & 24 & 524 & 529 \\
\hline M_0 & 244 & 244 & 365 & 350 & 609 & 594 & 28 & 32 & 1,117 & 1,144 \\
\hline W_0 & 270 & $\mathrm{n} / \mathrm{a}$ & 278 & $\mathrm{n} / \mathrm{a}$ & 548 & $\mathrm{n} / \mathrm{a}$ & 18 & $\mathrm{n} / \mathrm{a}$ & 904 & $\mathrm{n} / \mathbf{a}$ \\
\hline
\end{tabular}

substantially increased, no inhibition was obvious. It has to remain open if the different results were due to the type of manure used (pig manure vs. dairy farm manure) or if the combined effect of sulfonamides and manure on the microbial parameters studied (substrate-induced respiration vs. urease activity) was different among the two studies. The temporal trend of UA in treatment M 900 is contrasting the results for M_0 and M_90. The explanation why UA in M_900 was similar to the W-treatments, but completely different from treatments $M_{-} 0$ and $M_{-} 90$ has yet to remain unresolved.

\section{Conclusions}

Sulfonamides clearly affected both the function (enzyme activities) and structural diversity (PLFA) of the soil microbial community. Although the soil used receives regular input of manure that contains several antibiotics and thus the soil microbial community is expected to be to some extent adapted to the presence of antibiotics, the microbial community was affected by sulfonamides even at relatively low concentrations. The effect of sulfonamides on UA was present over a period of at least 16 days. Further research is needed on long-term effects of sulfonamides on the soil microbial community, on the effect of repeated inputs of sulfonamides on soil microorganisms, and on the adaptation of the soil microbial community under the management practices typical for dairy farms like the one studied here. Moreover, to better establish cause and effect relationships over time, the bioavailable sulfonamide concentration should be determined in conjunction with soil microbial parameters.

This study provides insight into the combined effect of three sulfonamides typically used in dairy farms. Although the general findings can be expected to be similar, studies with each individual sulfonamide are necessary to establish potential synergistic or antagonistic effects of the sulfonamide mixture. Moreover, as we measured an effect on UA even at the lowest sulfonamide concentration of $0.9 \mu \mathrm{g} \mathrm{g}_{\mathrm{dm}}{ }^{-1}$, future studies should aim at determining effects of sulfonamides at concentrations even below this concentration 
No effect of sulfonamides on enzymatic activities was observed when soil microbial growth was not stimulated by the addition of easily available carbon. This points to a limitation of microbial growth by the availability of organic carbon in the soil used. Consequently, on the field scale, we expect the highest effect of sulfonamides when the availability of organic carbon is high, e.g., after input of fresh plant material following harvesting. When transferring results from this study to the field scale, however, it has to be taken into account that incubations as carried out here are static systems that allow the variation of individual parameters under otherwise constant boundary conditions. In comparison, especially under management practices of the studied type of dairy farms, the application of manure is a highly dynamic process: a large amount of manure is used for irrigation of previously dry sandy soil, and due to the climatic conditions the soil water is evaporating relatively quickly after infiltration of the manure. Thus, hydraulic conditions are highly transient. Further research should take into account such dynamic boundary conditions when the effects of antibiotics on the soil microbial community are studied.

Acknowledgments This study was financially supported by grants from the Bavaria California Technology Center (BaCaTeC) to MR and the German Academic Exchange Service (DAAD) to IRG. We thank two anonymous reviewers for their constructive comments on earlier versions of this manuscript.

\section{References}

Böhme L, Langer U, Böhme F (2005) Microbial biomass, enzyme activities and microbial community structure in two European long-term field experiments. Agric Ecosyst Environ 109:141152

Bol R, Kandeler E, Amelung W, Glaser B, Marx MC, Preedy N, Lorenz K (2003) Short-term effects of dairy slurry amendment on carbon sequestration and enzyme activities in a temperate grassland. Soil Biol Biochem 35:1411-1421

Esiobu N, Armenta L, Ike J (2002) Antibiotic resistance in soil and water environments. Int J Environ Health Res 12:133-144

Frostegard A, Tunlid A, Baath E (1991) Microbial biomass measured as total lipid phosphate in soils of different organic content. J Microbiol Meth 14:151-163

Hackl E, Pfeffer M, Donat C, Bachmann G, Zechmeister-Boltenstern $S$ (2005) Composition of the microbial communities in the mineral soil under different types of natural forest. Soil Biol Biochem 37:661-671

Halling-Sørensen B, Nors Nielsen S, Lanzky PF, Ingerslev F, Holten Lützhøft HC, Jørgensen SE (1998) Occurrence, fate and effects of pharmaceutical substances in the environment-a review. Chemosphere 36:357-393

Hammesfahr U, Heuer H, Manzke B, Smalla K, Thiele-Bruhn S (2008) Impact of the antibiotic sulfadiazine and pig manure on the microbial community structure in agricultural soils. Soil Biol Biochem 40:1583-1591

Hamscher G, Pawelzick HT, Höper H, Nau H (2005) Different behaviour of tetracyclines and sulfonamides in sandy soils after repeated fertilization with liquid manure. Environ Toxicol Chem $24: 861-868$
Harter T, Davis H, Mathews MC, Meyer RD (2002) Shallow groundwater quality on dairy farms with irrigated forage crops. J Contam Hydrol 55:287-315

Heise J, Höltge S, Schrader S, Kreuzig R (2006) Chemical and biological characterization of non-extractable sulfonamide residues in soil. Chemosphere 65:2352-2357

Kahle M, Stamm C (2007) Time and pH-dependent sorption of the veterinary antimicrobial sulfathiazole to clay minerals and ferrihydrite. Chemosphere 68:1224-1231

Kandeler E, Gerber H (1988) Short-term assay of soil urease activity using colorimetric determination of ammonium. Biol Fertil Soils 6:68-72

Kandeler E, Kampichler C, Horak O (1996) Influence of heavy metals on the functional diversity of soil microbial communities. Biol Fertil Soils 23:299-306

Kandeler E, Stemmer M, Klimanek EM (1999) Response of soil microbial biomass, urease and xylanase within particle size fractions to long-term soil management. Soil Biol Biochem 31:261-273

Klose S, Tabatabai MA (1999) Urease activity of microbial biomass in soils. Soil Biol Biochem 31:205-211

Kong WD, Zhu YG, Fu BJ, Marschner P, He JZ (2006) The veterinary antibiotic oxytetracycline and cu influence functional diversity of the soil microbial community. Environ Pollut 143:129-137

Kotzerke A, Sharma S, Schauss K, Heuer H, Thiele-Bruhn S, Smalla K, Wilke BM, Schloter M (2008) Alterations in soil microbial activity and $N$-transformation processes due to sulfadiazine loads in pig-manure. Environ Pollut 153:315-322

Madigan MT, Martinko JM, Dunlap PV, Clark DP (2009) Brock biology of microorganisms. 12th international ed., Pearson, San Francisco

Sarmah AK, Meyer MT, Boxall ABA (2006) A global perspective on the use, sales, exposure pathways, occurrence, fate and effects of veterinary antibiotics (VAs) in the environment. Chemosphere 65:725-759

Scheffer P, Schachtschabel P, Blume H-P, Brümmer G, Hartge KH, Schwertmann U, Auerswald K, Beyer L, Fischer WR, KögelKnaber 1, Renger M, Strebel O (1998) Lehrbuch der Bodenkunde, 14th edn. Ferdinand Enke, Stuttgart, p 494

Schmitt $\mathrm{H}$, Haapakangas $\mathrm{H}$, van Beelen $\mathrm{P}$ (2005) Effects of antibiotics on soil microorganisms: time and nutrients influence pollutioninduced community tolerance. Soil Biol Biochem 37:1882-1892

Schmitt H, van Beelen P, Tolls J, van Leeuwen CL (2004) Pollutioninduced community tolerance of soil microbial communities caused by the antibiotic sulfachloropyridazine. Environ Sci Technol 38:1148-1153

Schmitt A, Glaser B, Borken W, Matzner E (2008) Repeated freezethaw cycles changed organic matter quality in a temperate forest soil. J Plant Nutr Soil Sci 171:707-718

Snedecor GW, Cochran WT (1989) Statistical methods. Ames, lowa

Thalmann A (1968) Zur Methodik der Bestimmung der Dehydrogenaseaktivität im Boden mittels Triphenyltetrazoliumchlorid (TTC). Landwirtsch Forsch 21:249-258

Thiele-Bruhn S, Beck IC (2005) Effects of sulfonamide and tetracycline antibiotics on soil microbial activity and microbial biomass. Chemosphere 59:457-465

Watanabe N, Harter T, Bergamaschi BA (2010) Environmental occurrence of antibiotics from dairy farms. In press

Watanabe N, Harter TH, Bergamaschi BA (2008) Environmental occurrence and shallow ground water detection of the antibiotic monensin from dairy farms. J Environ Qual 37:78-85

Zelles L (1999) Fatty acid patterns of phospholipids and lipopolysaccharides in the characterisation of microbial communities in soil: a review. Biol Fertil Soils 29:111-129

Zielezny Y, Groeneweg J, Vereecken H, Tappe W (2006) Impact of sulfadiazine and chlorotetracycline on soil bacterial community structure and respiratory activity. Soil Biol Biochem 38:2372-2380 